\title{
Nursing diagnoses in adults and elderlies in the preoperative period: a comparative study
}

\author{
Diagnósticos de enfermagem em adultos e idosos no pré-operatório: estudo comparativo \\ Diagnósticos de enfermería en adultos y ancianos en el preoperatorio: estudio comparativo
}

Luana Barbosa dos Santos Monteiro'

ORCID: 0000-0001-7128-5152

Priscilla Alfradique de Souza"

ORCID: 0000-0002-4625-7552

Priscila Francisca Almeida'

ORCID: 0000-0002-5716-9136

Graziele Ribeiro Bitencourt"II

ORCID: 0000-0002-9130-9307

Cintia Silva Fassarella'

ORCID: 0000-0002-2946-7312

'Universidade do Estado do Rio de Janeiro. Rio de Janeiro, Rio de Janeiro, Brazil.

"Universidade Federal do Estado do Rio de Janeiro.

Rio de Janeiro, Rio de Janeiro, Brazil.

"' Universidade Federal Fluminense. Niterói, Rio de Janeiro, Brazil.

How to cite this article:

Monteiro LBS, Souza PA, Almeida PF, Bittencourt GR,

Fassarela CS. Nursing diagnoses in adults and elderlies in the preoperative period: a comparative study.

Rev Bras Enferm. 2019;72(Suppl 2):56-63. doi: http://dx.doi.org/10.1590/0034-7167-2017-0959

Corresponding Author:

Luana Barbosa dos Santos Monteiro

E-mail: luana.bds.enf@gmail.com

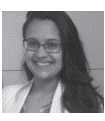

Submission: 12-26-2017 Approval: 02-18-2019

\section{ABSTRACT}

Objective: Analyze the nursing diagnoses of NANDA-I Taxonomy in hospitalized adults and elderlies in preoperative of general surgery and proctology. Method: cross-sectional study, exploratory, quantitative approach, developed in the general surgery ward, between March and August, 2017. Inferential statistical analysis performed using Chisquare and Fisher test, considering p-value $<0.05$ and $95 \%$ confidence interval. Results: Of 51 participants, $32(62.7 \%)$ were adults and 19 (37.3\%) elderlies. In adults prevailed anxiety (81.3\%), fear (50\%), risk for infection (43.8\%), and risk for delayed surgical recovery (37.5\%). In elderlies, anxiety (68.4\%), risk for infection (63.2\%), impaired comfort (57.9), and risk for delayed surgical recovery (52.6\%) prevailed. Anxiety was significant in adults $(p=0.028)$; impaired dentition ( $p=0.001)$, and impaired comfort $(p=0.008)$ in elderlies. Conclusion: specificities of pre-surgical care rarely identified were evidenced, especially related to risk for infection and risk for delayed surgical recovery.

Descriptors: Perioperative Nursing; Nursing Diagnosis; Nursing Process; General Surgery; Colorectal Surgery.

\section{RESUMO}

Objetivo: Analisar os diagnósticos de enfermagem da Taxonomia NANDA-I em adultos e idosos hospitalizados no pré-operatório de cirurgia geral e proctologia. Método: Estudo transversal, exploratório, de abordagem quantitativa, desenvolvido na enfermaria de cirurgia geral entre março e agosto de 2017. Realizada análise estatística inferencial pelos testes de Qui-quadrado e Fisher, considerando $p$-valor $<0,05$ e intervalo de confiança de 95\%. Resultados: Dos 51 participantes, 32 (62,7\%) eram adultos e 19 (37,3\%), idosos. Nos adultos predominaram: ansiedade (81,3\%), medo (50\%), risco de infecção $(43,8 \%)$ e risco de recuperação cirúrgica retardada $(37,5 \%)$. Nos idosos: ansiedade $(68,4 \%)$, risco de infecção $(63,2 \%)$, conforto prejudicado $(57,9 \%)$ e risco de recuperação cirúrgica retardada $(52,6 \%)$. Teve-se significância nos diagnósticos ansiedade $(p=0,028)$ em adultos; dentição prejudicada $(p=0,001)$ e conforto prejudicado em idosos $(p=0,008)$. Conclusão: Evidenciaram-se especificidades do cuidado no précirúrgico raramente identificadas, relacionadas principalmente ao risco de infecção e risco de recuperação cirúrgica retardada.

Descritores: Enfermagem Perioperatória; Diagnóstico de Enfermagem; Processo de Enfermagem; Cirurgia Geral; Cirurgia Colorretal.

\section{RESUMEN}

Objetivo: analizar los diagnósticos de enfermería de la taxonomía NANDA-I en adultos y ancianos hospitalizados en el preoperatorio de cirugía general y proctología. Método: estudio transversal exploratorio, abordaje cuantitativo, desarrollado en la sala de cirugía general entre marzo y agosto de 2017. Realizado análisis estadística inferencial con la prueba de Chi-cuadrado y Fisher, considerando valor de $p<0,05$ con intervalo de confianza 95\%. Resultados: De 51 participantes, 32 (62,7\%) fueron adultos y 19 (37,3\%) ancianos. En adultos predominó: ansiedad (81,3\%), miedo (50\%), riesgo de infección $(43,8 \%)$ y riesgo de retraso de la recuperación quirúrgica $(37,5 \%)$. En los ancianos: ansiedad $(68,4 \%)$, riesgo de infección $(63,2 \%)$, incomodidad $(57,9 \%)$ y riesgo de retraso en la recuperación quirúrgica $(52,6 \%)$. Tuvieron significancia estadística los diagnósticos de ansiedad ( $p=0.028)$ en adultos, deterioro de la dentición $(p=0.001)$ y incomodidad en ancianos ( $p=0.008)$. Conclusión: se evidenciaron especificidades del cuidado en el prequirúrgico raramente identificadas, relacionadas principalmente con el riesgo de infección y el riesgo de retraso en la recuperación quirúrgica.

Descriptores: Enfermería Perioperatoria; Diagnóstico de Enfermería; Proceso de Enfermería; Cirugía General; Cirugía Colorrectal. 


\section{INTRODUCTION}

Although a considerable number of elderly people present a healthy aging and tolerate the surgical procedure without intercurrences, it is observed the frequent morbimortality greater in the elderly, when compared to the adults ${ }^{(1)}$. On the other hand, the adult needs effective and quality surgical care, in order to provide a return to the daily routine and work activities.

This can be due to the aging process of the Brazilian population, with an increase in the number of elderly people, currently representing 20 million of the population. It is estimated that by the year 2025 , this number of people aged 60 and over will reach 32 million ${ }^{(2)}$. Thus, more attention and an increasingly individualized care of the nursing team is required, especially those with comorbidities.

Associated with this fact, it is estimated that the number of elective surgeries in Brazil increased $11.7 \%$ in 2012, increasing from $2,120,580$ to 2,370,039 in 2014. The Ministry of Health's investment increased from $R \$ 1.04$ billion to $R \$ 1.33$ billion, corresponding to a growth of $27.2 \%$ in order to seek measures to prevent and control risks ${ }^{(3)}$. In addition, the number of general and proctologic surgeries increased to 51 and 186 quarterly surgeries, respectively ${ }^{(4)}$.

The preoperative phase in this context is understood from the moment the patient makes the decision on the surgical intervention until the transfer to the operating room table ${ }^{(4)}$. Thus, it is the responsibility of the nurse to plan the patient's care in the preoperative period, including attending to their biopsychospiritual needs, as well as providing guidance on the surgical procedure, physical preparation and risk prevention. All in order to prevent postoperative complications that may interfere with recovery and regular return to activities ${ }^{(5)}$.

The accurate perception of the nurses working in this period can contribute to the patient's coping with the surgery, insofar as the guidelines help to reduce the anxiety, fears and restlessness caused by the anesthetic-surgical procedure. It can also provide care that improves the patient's condition in relation to physical and emotional stability as well as safety to continue the procedure ${ }^{(6)}$.

In addition, the lack of a specific preoperative care protocols may prolong the time of postoperative hospitalization. As well as the complexity of nursing care, the difficulty of implementing the Nursing Care Systematization (Sistematização da Assistência de Enfermagem - SAE) and the absence of a standardized language, with little evidence on essential nursing diagnoses, are characteristics that directly interfere in the nursing care quality ${ }^{(5-7)}$.

The literature's review was conducted using the Virtual Health Library in the databases Literatura Latino-Americana e do Caribe em Ciências da Saúde (LILACS) and Medical Literature and Retrieval System Online (MEDLINE), with the following descriptors:"Preoperative nursing and general surgery"; "Preoperative nursing and colorectal surgery";"Nursing diagnosis and general surgery";"Nursing diagnosis and colorectal surgery"; and "Nursing diagnosis and preoperative". Of the five articles found, two were in the LILACS. One of these studies identified the frequency of the most relevant diagnoses in a surgical clinic, with a target audience of postoperative patients ${ }^{(6)}$. Already another study suggested nursing diagnoses for preoperative care. However, in this initial research, the aim was to understand patients in the preoperative period of esophageal surgeries, exclusively ${ }^{(7)}$.

In addition, three articles were found in the MEDLINE. However, none specifically addressed preoperative nursing diagnoses. In the first one, the necessary information to patients and relatives in the perioperative period were approached ${ }^{(8)}$. In the second, the preoperative verification was treated as a benefit for patient safety ${ }^{(9)}$. The last one presents a discussion about providing information to the patient before and after the surgical procedure, as a proposal to improve the healing ${ }^{(10)}$.

In this context, the Resolution COFEN (Nursing Federal Council) no. 358/2009 provides about SAE and the implementation of the nursing process (NP) in public or private environments in which professional nursing care takes place ${ }^{(11)}$. NP has five steps: data collection, nursing diagnosis (ND), planning, implementation and evaluation of care ${ }^{(11)}$. According to the taxonomy of the International NANDA (NANDA-I), nursing diagnosis is defined as "a clinical judgment about a human response to health conditions, life processes; or a vulnerability of a person, family, group, or community to a response"(12).

This taxonomy is the most widely used in the world, since it has a previous theoretical basis and seeks to understand the individual's responses, such as health problems or complaints, needs and afflictions ${ }^{(12)}$. Thus, it was determined as a research question: "What are the frequent nursing diagnoses in adults and elderlies hospitalized in preoperative general surgery and proctology, based on the NANDA-I taxonomy?".

For the development of a good quality preoperative nursing care, it is essential to perform the NP with all its stages, including the nursing diagnoses. This fact contrasts with the incipient number of studies related to ND in the preoperative period, especially with regard to general surgery and proctology, bringing the need for new studies in this area.

\section{OBJECTIVE}

To analyze the nursing diagnoses of NANDA-ITaxonomy in adults and elderly hospitalized in the preoperative period of general surgery and proctology. Specific objectives: 1) To identify nursing diagnoses, defining characteristics, and related or risk factors; and 2) To compare nursing diagnoses identified in adults and elderlies hospitalized in the preoperative period of general surgery and proctology.

\section{METHOD}

\section{Ethical aspects}

The research was submitted for consideration and approved by the hospital's ethics committee. All ethical and legal standards related to research with human beings were respected, according to the Resolution no. 510/2016 and the Resolution no. 466/2012 of the National Health Council, which provide on the standards applicable to research in Human and Social Sciences ${ }^{(13-14)}$. The subjects' participation was preceded by the signing of the Informed Consent Form and maintenance of confidentiality of the information.

\section{Design, place of study and period}

This is a research with a quantitative approach, of exploratory and transversal type ${ }^{(15)}$, with a total of 51 participants, 32 (62.7\%) adults and 19 (37.3\%) elderlies. The scenario was a general surgery ward of a university hospital in Rio de Janeiro that has ten beds for 
men and eight for women. Of these ten beds for men, two are for proctology patients, and of the eight beds for women, two are for proctology patients. The ward has a head nurse, nursing residents in a surgical clinic and nursing technicians. Data collection was performed in the period from March to August, 2017, with an average of 3 visits per week to the ward.

\section{Population, inclusion and exclusion criteria}

Adults and elderlies in preoperative or immediate mediate constituted as participants of the research. The inclusion criteria were adults or elderly in the preoperative period. In the elderly participants, people over 65 years of age, those with preserved cognitive functions were included, according to information collected in medical records, to answer the questions of the data collection instrument, with or without companions. This capacity was analyzed by the absence of NANDA-I nursing diagnoses from the cognition domain: impaired memory, acute confusion or chronic confusion. Exclusion criteria were patients admitted for diagnostic procedures such as biopsy or preoperative exams.

\section{Study protocol}

Sample selection was performed in a non-probabilistic manner, in a random method ${ }^{(16)}$. Therefore, a nurse specialized in medical-surgical nursing was called in this study as an auxiliary researcher and responsible for data collection. The head researcher was responsible for the training and supervision of the auxiliary researcher. She is a teacher, PhD in nursing, with publications and specialist in the area of elderly and medical-surgical. A theoretical class about SAE and nursing classifications was given by the head researcher, with emphasis on NANDA-I and specifics of the aging process for this training. Then, a practical study was carried out, with a visit to the data collection scenario and a direct approach to the adult and elderly patient by the head researcher in the presence of the assistant. Subsequently, the auxiliary researcher (with the presence of the main one) collected data from 5 patients. The doubts were answered and, only after this moment, the data collection for this study began. All patients hospitalized during the data collection period and who met the inclusion criteria were included in the sample.

A data collection instrument with two parts and mixed questions was prepared: the first part composed of the characterization of the participants and the second part with objective and subjective questions related to the domains of taxonomy of NANDA-I (Chart 1). For this purpose, this instrument was developed from a literature review aimed at the preoperative period ${ }^{(1,5-7,9-11)}$ and adapted according to the domains of NANDA-I, version 2015-2017 ${ }^{(12)}$. These elements provided verification of possible changes to identify risk diagnoses, those focused on the problem and/or health promotion, their defining characteristics, related factors and risk factors.

Chart 1 - Instrument for data collection of nursing diagnoses in preoperative adults and elderlies, Rio de Janeiro, Rio de Janeiro, Brazil, 2017

\begin{tabular}{|c|c|}
\hline Domain & Evaluation \\
\hline Health Promotion & $\begin{array}{l}\text { Did you get any information about the surgical procedure? Y ( ) N ( ) } \\
\text { Did you sign the Informed Consent Form? Y ( ) N () } \\
\text { Do you have surgical risk in medical records? Y ( ) N ( ) }\end{array}$ \\
\hline Nutrition & $\begin{array}{l}\text { Weight: } \quad \text { Height: } \_ \text {BMl: } \\
\text { Do you have any difficulty eating? ( ) N ( ) Which ones? } \\
\text { Are you oriented towards the maintenance of perioperative fast? Y ( ) N ( ) }\end{array}$ \\
\hline $\begin{array}{l}\text { Elimination and } \\
\text { exchange }\end{array}$ & $\begin{array}{l}\text { Breathing: } \\
\text { Diuresis: Spontaneous ( ) Diapers ( ) Bedpans or urinal ( ) Nefrostomy ( ) } \\
\text { Urinary Catheter: Aspect: } \quad \text { Smell:__ Urinary alterations: } \\
\text { Evacuations: Normal ( ) Altered ( ) Absent for__days ( ) Device Use: } \\
\text { Characteristics: ( ) Consistent ( ) Pasty ( ) Semi-liquid ( ) Liquid ( ) Mucus ( ) Enterorrhagia ( ) Others: } \\
\text { Vomit: Y ( ) N ( )_ X/days Nausea: Y ( ) N ( ) } \\
\text { Characteristics: ( ) Food ( ) Mucous ( ) Bilious ( ) Fecaloid ( ) Hemorrhagic }\end{array}$ \\
\hline Activity and rest & $\begin{array}{l}\text { Walking: Normal () With restrictions ( ) Which ones? } \\
\text { Immobility: Y () N( ) Why? } \\
\text { Sleep pattern: Good ( ) Regular ( ) Absent ( ) Number of hours in } 24 \text { hours: }\end{array}$ \\
\hline $\begin{array}{l}\text { Perception and } \\
\text { cognition }\end{array}$ & $\begin{array}{l}\text { Orientation level: Oriented ( ) Desoriented ( ) Confused ( ) Unconscious ( ) } \\
\text { Altered memory () } \\
\text { Behavior: High anxiety ( ) Ansiety () Agitated ( ) Calm ( ) Apathetic ( ) Interested ( ) } \\
\text { Hearing: Normal ( ) Decreased ( ) Absent ( ) Orthosis ( ) } \\
\text { Vision: Normal ( ) Absent ( ) Decreased ( ) Obs.: } \\
\text { Comunication: Normal Talk ( ) Refusal to talk () Dysphasia ( ) Aphasia ( ) }\end{array}$ \\
\hline Self-perception & $\begin{array}{l}\text { Has/expresses negative feelings? Y ( ) N ( ) Which ones? } \\
\text { Feeling about the surgical procedure }\end{array}$ \\
\hline Role relationship & Present/refer to changes in relationships? Y ( ) N ( ) Which ones? \\
\hline Sexuality & Any alteration? Y ( ) N ( ) Which one? \\
\hline
\end{tabular}




\begin{tabular}{|c|c|}
\hline Domain & Evaluation \\
\hline $\begin{array}{l}\text { Coping and stress } \\
\text { tolerance }\end{array}$ & $\begin{array}{l}\text { Any recent changes? Y ( ) N ( ) If the answer is Yes, which one? } \\
\text { Anxiety: because of } \\
\text { Living under stress? Y ( ) N ( ) If the answer is Yes, which one? } \\
\text { Do you plan your daily activities? Y ( ) N ( ) If not, why not? }\end{array}$ \\
\hline & $\begin{array}{l}\text { Alteration in skin integrity: Intact skin ( ) Intact mucosa ( ) Edema: Y ( ) N ( ) } \\
\text { Open Lesion: Erythema ( ) Pressure Ulcer ( ) Pustules: Y ( ) N ( ) } \\
\text { Hygiene: Adequate ( ) Satisfactory ( ) Regular ( ) Poor ( ) Note:__ } \\
\text { Invasive equipment? Y ( ) N ( ) Note: } \\
\text { Presence of Stoma: Y ( ) N ( ) Body part and aspect__ Comorbidities: Y ( ) N ( ) Which ones? }\end{array}$ \\
\hline Safety and protection & $\begin{array}{l}\text { Daily use medication: } \\
\text { Ethylism: } \mathrm{Y} \text { ( ) N ( ) Ex-Ethylist: } \mathrm{Y} \text { ( ) N ( ) Time not using: } \\
\text { Smoker: } \mathrm{Y} \text { ( ) N ( ) Ex-smoker: Y ( ) N ( ) Time not using:___ Time not using: } \\
\text { Illicit drug use: Y ( ) N ( ) Which ones? } \\
\text { Precaution: S ( ) N ( ) Contact( ) Air ( ) Droplet ( ) Reason:__ }\end{array}$ \\
\hline Comfort & $\begin{array}{l}\text { Displays some discomfort: Y ( ) N ( ) Type: } \\
\text { Pain: Y ( ) N ( ) Numerical pain intensity scale (1 to 10): ___ Body part: }\end{array}$ \\
\hline
\end{tabular}

The medical record was used as a complement for the evaluation of exams and observation of the signature in the Informed Consent Form. The research participants were interviewed in a single moment, with an average duration of 35 minutes each one.

\section{Analysis of results and statistics}

The auxiliary researcher performed data analysis and later, for greater reliability of the results, the head researcher reassessed the data. A diagnostic analysis of each patient and, subsequently of each domain, was conducted. Descriptive and inferential statistical analysis was used to describe and synthesize the data. The data set can be described in the form of value distribution, central tendency and variability ${ }^{(15)}$, using the percentage limit defined by the main diagnoses identified, which corresponded to $21 \%$ in the elderlies and $25 \%$ in adults, which were the most prevalent, as established in previous studies ${ }^{(7,17-18)}$.

The data were tabulated in the Excel software version 2010 and, for data analysis; the software Statistical Package for the Social Sciences (SPSS), version 20.0 was used. We used the inferential statistical analysis from Chi-square analyses in the comparison of data between adults and the elderlies. We performed Chi-square tests and the Fisher's test for variables with inconclusive. It was considered $p$-value $<0.05$ and confidence interval of $95 \%$. The subjective data were treated in a complementary way to the subjective findings.

\section{RESULTS}

As sample composition, 51 participants were obtained in the study, 32 (62.7\%) adults and 19 (37.3\%) elderly. In the adult age group, the predominant gender was female, with 19 (59.4\%) women. In the elderly age group, the predominant gender was male, with 13 (68.4\%) man participants (Table 1).

In terms of age, adults had the majority (17 people - $53.1 \%)$, in the age group between 50 and 59 years. Among the elderlies, the age group of 60 to 69 years predominated (11 people - 57.9\%). Among the adults, the level of education in greater number was the complete high school, with 14 individuals (43.8\%), the elderlies' level of education in greater number was the incomplete elementary school, with 11 (57.9\%) participants. In the marital status, the group of the married presented bigger quantity, between adults $43.8 \%$ ( 14 people) and between elderlies $47.4 \%$ ( 9 people). The biggest number in adults was of formal workers (14 - 43.8\%); the majority of the other group (14 - 73.7\%) was composed of retired elderlies. They were statistically significant between the groups, age $(p=0.013)$, schooling $(p=0.001)$ and occupation $(p=0.001)$.

Table 1 - Distribution of adults $(\mathrm{N}=32)$ and elderlies $(\mathrm{N}=19)$ in preoperative according to gender, age, schooling, occupation and type of surgery, Rio de Janeiro, Rio de Janeiro, Brazil, 2017

\begin{tabular}{lccc}
\hline Sociodemographic data & $\begin{array}{c}\text { Adults } \\
\mathbf{n}(\%)\end{array}$ & $\begin{array}{c}\text { Elderlies } \\
\mathbf{n}(\%)\end{array}$ & $\begin{array}{c}\boldsymbol{p} \text { value } \\
\text { test } \mathbf{X}^{\mathbf{2}}\end{array}$ \\
\hline Sex & & & \\
Female & $19(59.4)$ & $6(31.6)$ & 0.055 \\
Male & $13(40.6)$ & $13(68.4)$ & \\
Age & & & \\
$20-39$ & $8(25)$ & - & \\
$40-49$ & $7(21.9)$ & - & $0.013^{*}$ \\
$50-59$ & $17(53.1)$ & - & \\
$60-69$ & - & $11(57.9)$ & \\
$70-79$ & - & $7(36.8)$ & \\
$80-89$ & - & $1(5.3)$ & \\
Education Level & $6(18.8)$ & $11(57.9)$ & \\
Did not finish elementary school & $2(6.2)$ & $7(36.8)$ & \\
Primary school & $4(12.5)$ & - & $0.001^{*}$ \\
Did not finish high school & $14(43.8)$ & $1(5.3)$ & \\
High school & $1(3.1)$ & - & \\
Did not finish college & $4(12.5)$ & - & \\
College & $1(3.1)$ & - & \\
Postgraduation & & & \\
Occupation & $5(15.6)$ & $14(73.7)$ & \\
Retired & $2(6.2)$ & - & \\
Unemployed & $14(43.8)$ & $4(21.1)$ & $0.001^{*}$ \\
Formal Work & $10(31.2)$ & - & \\
Informal Work & $1(3.1)$ & $1(5.3)$ & \\
Domestic work & & & \\
\hline
\end{tabular}

Note: ${ }^{*} p$-value $\leq 0.05$.

According to the types of surgeries, the most commonly performed in adults were cholecystectomy in 10 (31.2\%) participants, followed by hernioplasty in $6(18.8 \%)$ participants. In the elderly, the main surgery was rectosigmoidectomy, with in 5 (26.3\%) participants, and gastrectomy in $3(15.8 \%)$ participants. The following 
types of surgeries were also identified: colectomy, gastroenteroanastomosis, hepatectomy, ileostomy, pancreatectomy, pyloroplasty, sarcomaendectomy, sigmoidectomy and thyroidectomy.

Eighty different ND were identified. In adults, a total of 164 ND was identified, with a mean of 5 diagnoses for each adult. In the elderlies, 92 ND were identified, obtaining an average of 4.8 diagnoses for each elderly. Of these, the 15 main ND and their respective domains are presented, 11 ND of the problem focus type and 4 of risk (Table 2), these are the most representative of the total sample and evidenced in more than $25 \%$ of adults and more than $21 \%$ of the elderly.
The safety and protection domains were the most identified in the diagnoses with a significant quantity in both groups, besides presenting most of the ND risk evidenced. The most evidenced ND was "risk of infection", with a quantity of 14 in adults (43.8\%) and 12 in the elderlies (63.2\%); followed by "risk for delayed surgical recovery" with 12 (37.5\%) in adults and 10 (52.6\%) in the elderlies, diagnoses directly related to the perioperative period. "Impaired skin integrity" also stood out, with 9 (28.1\%) adults and 6 (31.6\%) elderly participants; "risk for allergic reaction" also presented a relevant amount, with 8 (25\%) in adults and 3 (15.8\%) elderly; and "risk for perioperative positioning injury" was evidenced in 8 (25\%) adults

Table 2 - Comparison between the distribution of nursing diagnoses by domains in adults $(n=32)$ and elderlies $(n=19)$ in the preoperative period, Rio de Janeiro, Rio de Janeiro, Brazil, 2017

\begin{tabular}{|c|c|c|c|c|}
\hline Domains & Titles of nursing diagnoses & $\begin{array}{c}\text { Adults } \\
\text { n (\%) }\end{array}$ & $\begin{array}{c}\text { Elderlies } \\
\text { n (\%) }\end{array}$ & $\begin{array}{l}p \text { value } \\
\text { test } X^{2}\end{array}$ \\
\hline Nutrition & $\begin{array}{l}\text { Overweight } \\
\text { Obesity }\end{array}$ & $\begin{array}{c}9(28.1) \\
8(25)\end{array}$ & $\begin{array}{l}4(21.1) \\
2(10.5)\end{array}$ & $\begin{array}{l}0,038^{F} \\
0,022^{F}\end{array}$ \\
\hline Activity/Rest & Disturbed sleep pattern & $12(37.5)$ & $5(26.3)$ & $0,038^{\mathrm{F}}$ \\
\hline Coping / Stress Tolerance & $\begin{array}{l}\text { Anxiety } \\
\text { Fear } \\
\text { Relocation Stress Syndrome } \\
\text { Stress overload }\end{array}$ & $\begin{array}{l}26(81.3) \\
16(50) \\
12(37.5) \\
8(25)\end{array}$ & $\begin{array}{l}13(68.4) \\
7(36.8) \\
4(21.1) \\
1(5.3)\end{array}$ & $\begin{array}{l}0,028 \\
0,029 \\
0,026^{F} \\
0,006^{F}\end{array}$ \\
\hline Safety and protection & $\begin{array}{l}\text { Risk for infection } \\
\text { Risk for delayed surgical recovery } \\
\text { Impaired Skin Integrity } \\
\text { Risk for allergic reaction } \\
\text { Risk for perioperative positioning injury } \\
\text { Impaired dentition }\end{array}$ & $\begin{array}{l}14(43.8) \\
12(37.5) \\
9(28.1) \\
8(25) \\
8(25) \\
2(6.3)\end{array}$ & $\begin{array}{l}12(63.2) \\
10(52.6) \\
6(31.6) \\
3(15.8) \\
2(10.5) \\
7(36.8)\end{array}$ & $\begin{array}{l}0,016 \\
0,016 \\
0,041^{F} \\
0,024^{F} \\
0,022^{F} \\
0,001^{F}\end{array}$ \\
\hline Comfort & $\begin{array}{l}\text { Impaired comfort } \\
\text { Acute pain }\end{array}$ & $\begin{array}{l}11(34.4) \\
9(28.1)\end{array}$ & $\begin{array}{l}11(57.9) \\
5(26.3)\end{array}$ & $\begin{array}{l}0,008 \\
0,035^{\mathrm{F}}\end{array}$ \\
\hline Total & 15 & 164 & 92 & \\
\hline
\end{tabular}

Note: * p-value $\leq 0.05$; F: Exact Fisher Test.

Table 3 - Distribution of defining characteristics in adults $(n=32)$ and elderly $(n=19)$ preoperatively, Rio de Janeiro, Rio de Janeiro, Brazil, 2017

\begin{tabular}{|c|c|c|c|}
\hline Nursing diagnosis & Defining characteristics & $\begin{array}{l}\text { Adults } \\
\text { n (\%) }\end{array}$ & $\begin{array}{c}\text { Elderlies } \\
\text { n (\%) }\end{array}$ \\
\hline Overweight & $\mathrm{BMI}>25 \mathrm{~kg} / \mathrm{m} 2$ & $9(28.1)$ & $4(21.1)$ \\
\hline Obesity & $\mathrm{BMI}>30 \mathrm{~kg} / \mathrm{m} 2$ & $8(25)$ & $2(10.5)$ \\
\hline Disturbed sleep pattern & $\begin{array}{l}\text { Dissatisfaction with sleep } \\
\text { Alteration in sleep pattern }\end{array}$ & $\begin{array}{l}10(31.3) \\
7(21.9)\end{array}$ & $\begin{array}{l}4(21.1) \\
3(15.8)\end{array}$ \\
\hline Anxiety & $\begin{array}{l}\text { Restlessness } \\
\text { Apprehensiveness } \\
\text { Fear } \\
\text { Preoccupation } \\
\text { Worried about change in life event } \\
\text { Anguish } \\
\text { Alteration in sleep pattern }\end{array}$ & $\begin{array}{l}8(25) \\
7(21.9) \\
5(15.7) \\
16(50) \\
17(53.1) \\
5(15.7) \\
5(15.7)\end{array}$ & $\begin{array}{l}2(10.5) \\
1(5.3) \\
1(5.3) \\
9(47.4) \\
8(42.1) \\
1(5.3) \\
2(10.5)\end{array}$ \\
\hline Fear & $\begin{array}{l}\text { Apprehensiveness } \\
\text { Feeling of fear } \\
\text { Feeling of dread }\end{array}$ & $\begin{array}{c}8(25) \\
9(28.1) \\
8(25)\end{array}$ & $\begin{array}{l}2(10.5) \\
3(15.8) \\
4(21.1)\end{array}$ \\
\hline Stress overload & Stress & $6(18.8)$ & $1(5.3)$ \\
\hline Relocation stress syndrome & $\begin{array}{l}\text { Anxiety } \\
\text { Alteration in sleep pattern } \\
\text { Concern about relocation } \\
\text { Preoccupation }\end{array}$ & $\begin{array}{l}9(28.1) \\
5(15.7) \\
6(18.8) \\
6(18.8)\end{array}$ & $\begin{array}{l}2(10.5) \\
2(10.5) \\
2(10.5) \\
2(10.5)\end{array}$ \\
\hline Impaired skin integrity & $\begin{array}{l}\text { Alteration in skin integrity } \\
\text { Foreign matter piercing skin }\end{array}$ & $\begin{array}{l}5(15.7) \\
7(21.9)\end{array}$ & $\begin{array}{l}4(21.1) \\
4(21.1)\end{array}$ \\
\hline Impaired dentition & Absence of teeth & $2(6.3)$ & $7(36.8)$ \\
\hline Impaired comfort & Feeling of discomfort & $10(31.3)$ & $10(52.6)$ \\
\hline Acute pain & Self-report of intensity using standardized pain scale & $9(28.1)$ & $5(26.3)$ \\
\hline Total & 24 & 187 & 85 \\
\hline
\end{tabular}


and 2 (10.5\%) elderlies. In addition, the ND"impaired dentition"was identified only in 2 (6.3\%) adults; however, in the elderly, of the 19 participants, 7 (36.8\%) presented this diagnosis.

When comparing the groups, anxiety is the most frequent diagnosis in adults and elderly, with 26 (81.3\%) and 13 (68.4\%), respectively. In the comparative sequence, we observed in adult participants: fear in 16 (50\%), risk for infection in 14 (43.8\%), and risk for delayed surgical recovery in 12 (37.5\%). In the elderlies, it is identified: risk for infection in 12 (63.2\%), impaired comfort in 11 (57.9\%), and risk for delayed surgical recovery in 10 (52.6\%).

Twenty four defining characteristics (DCs) were evidenced (Table 3). In adults, $187 \mathrm{DC}$ were identified, with a mean of 6 characteristics for each adult and, in the elderlies, 85 DCs, with a mean of 5 characteristics for each elderly. We emphasize that 4 ND of risk (risk for infection, risk for delayed surgical recovery, risk for allergic reaction and risk for perioperative positioning injury) are not presented in table 3 because they are ND of risk and do not have DC, only risk factors.

The main identified DC are in ND of overweight, damage sleep pattern, impaired comfort and acute pain. Regarding the overweight, the DC "Body Mass Index/BMI > 25kg/m2" presented a quantitative of $9(28.1 \%)$ adults and $4(21.1 \%)$ elderlies. In the ND damage sleep pattern the DC highlighted were "dissatisfaction with sleep" in 10 (31.3\%) adults and 4 (21.1\%) elderlies, besides "alteration in sleep pattern", with 7 (21.9\%) adults and 3 (15.8\%) elderlies.

The ND "impaired comfort" showed as the main DC "feeling of discomfort", identified in 10 (31.3\%) adults and 10 (52.6\%) elderlies. The ND "acute pain" was also observed as relevant, the most evident DC was "self-reported intensity using standardized pain scale", in 9 (28.1\%) adults and 5 (26.3\%) elderly.

Concerning the related factors (RF), 10 RF was identified, using as basis the 15 main RFs that stood out in adults and elderlies. Among the selected ND, 88 RF were identified in adults and 59 in the elderlies (Table 4). Both groups had the same mean (3 FR for each person).

Among the main RFs, 5 predominant RF were evidenced, corresponding to a specific ND and more frequently in both groups. The ND anxiety, "important change in health condition" showed 20 (62.5\%) adults and 11 (57.9\%) elderlies, "situational crisis" with 6 (31.6\%) adults and 14 (43.8\%) elderlies. The ND fear, "learned response" showed 10 (31.3\%) adults and 6 (31.6\%) elderlies. The ND risk for infection, "chronic illness" showed 8 (25\%) adults and 9 (47.4\%) elderlies. Finally, the ND impaired comfort, showed"symptoms related to the disease", in 11 (34.4\%) adults and 8 (42.1\%) elderlies.

\section{DISCUSSION}

Even without statistical significance, the gender variable presented a higher number of hospitalized men when compared to women. In this research, the high male quantity may be associated with the high number of men hospitalized for inguinal hernia surgery. This procedure is predominantly observed in men, due to the development of manual labor that require handling of heavy materials ${ }^{(19)}$. Thus, the results found in this study contradict the evidence in the literature, since, according to the DATASUS ${ }^{(20)}$, in 2017, in Rio de Janeiro (RJ), the female population presented a higher number of hospitalizations $(197,996)$ than the male ones $(130,361)$.

Although the age difference between adults and elderlies showed statistical significance, the age group of adults that stood out in this study is not the same that stands out in Rio de Janeiro, in which the largest age group of hospitalization is from 20 to 29 years $^{(20)}$. On the other hand, the age group of the elderlies corroborates the age group of Rio de Janeiro, with a higher concentration of hospitalized patients aged between 60 and 69 .

Regarding the main surgeries in the elderlies, a study in a hospital in Santa Catarina observed that the main general surgeries were cholecystectomy, hernioplasty, gastrectomy and rectosigmoidectomy ${ }^{(21)}$, confirming the types of surgeries found in this study.

Surgical interventions such as coloproctology have become increasingly frequent in elderly people ${ }^{(22)}$. They correspond, on average, to $65 \%$ of general surgeries. Therefore, the elderly are exposed to surgical morbidities for a longer period of time ${ }^{(1)}$. Thus, it represents not only a threat to the patient's physical but also to the psychological integrity, due to the anxiety suffered in the hospital environment. The creation of ideas caused by waiting for a surgical intervention can influence the surgical procedure and its recovery. In addition, the emotional state can influence the functioning of the immune system and of the general physical condition ${ }^{(23)}$.

Due to the high number of comorbidities observed in the aging process, it is important to understand the elderly from a perspective of broad geriatric evaluation and the consequent impairment of geriatric syndromes when the evaluation is performed ${ }^{(17)}$. Previous studies corroborate the same findings when showing relevant ND in hospitalized elderlies who emphasize possible geriatric syndromes such as impaired dentition, risk for infection, acute pain, anxiety, impaired skin integrity and impaired comfort ${ }^{(18)}$.

Table 4 - Distribution of related factors in adults $(n=32)$ and elderlies $(n=19)$ in the preoperative period, Rio de Janeiro, Rio de Janeiro, Brazil, 2017

\begin{tabular}{|c|c|c|c|}
\hline Nursing diagnosis & Related factor & $\begin{array}{l}\text { Adults } \\
\text { n (\%) }\end{array}$ & $\begin{array}{l}\text { Elderlies } \\
\text { n (\%) }\end{array}$ \\
\hline Anxiety & $\begin{array}{l}\text { Threat to current status } \\
\text { Important change in health condition } \\
\text { Situational crisis }\end{array}$ & $\begin{array}{c}8(25) \\
20(62.5) \\
14(43.8)\end{array}$ & $\begin{array}{l}3(15.8) \\
11(57.9) \\
6(31.6)\end{array}$ \\
\hline Fear & Learned response & $10(31.3)$ & $6(31.6)$ \\
\hline Risk for delayed surgical recovery & $\begin{array}{l}\text { Obesity } \\
\text { Pharmaceutical Agent }\end{array}$ & $\begin{array}{l}6(18.8) \\
2(6.3)\end{array}$ & $\begin{array}{l}2(10.5) \\
4(21.1)\end{array}$ \\
\hline Risk for infection & $\begin{array}{l}\text { Chronic illness } \\
\text { Alteration in skin integrity }\end{array}$ & $\begin{array}{c}8(25) \\
5(15.7)\end{array}$ & $\begin{array}{l}9(47.4) \\
5(26.3)\end{array}$ \\
\hline Impaired comfort & $\begin{array}{l}\text { Illness-related symptoms } \\
\text { Treatment regimen }\end{array}$ & $\begin{array}{l}11(34.4) \\
4(12.5)\end{array}$ & $\begin{array}{l}8(42.1) \\
5(26.3)\end{array}$ \\
\hline Total & 10 & 88 & 59 \\
\hline
\end{tabular}


In the domain of nutrition, a characteristic for the identification of overweight and obesity was BMI. Such changes may increase the risk for surgical complications such as infections, atelectasis, fistulas, bleeding and dehiscence ${ }^{(24)}$. In the activity/rest domain, the characteristics of dissatisfaction with sleep and alteration in the sleep pattern, reported by adults and elderlies, were those that determined the selection of the ND disturbed sleep pattern. Therefore, it needs to be observed and considered. Sleep is understood as a basic human need; soon it becomes one of the factors that influence the quality of life of the human being at all times ${ }^{(6)}$.

To reduce the patient's fear and anxiety, the nurse should explain the procedure and answer the patient's doubts. Thus, the orientation needs to be performed clearly to be well understood, respecting the level of education and understanding of each patient ${ }^{(25)}$.

In addition, it is important for nurses to observe with a view to prevention the risk for infection and the risk factors of the patient ${ }^{(26)}$, but also to correlate chronic illnesses with related factors. In the elderlies, this aspect also needs to be observed due to the fragility of their immune system ${ }^{(27)}$. Thus, in the domain of safety and protection, we observed the highest number of identified ND, four of risk, based on the current health of the patients, their limitations and comorbidities.

The ND risk for delayed surgical recovery showed as main risk factors: obesity (more apparent in the elderlies); pharmaceutical agent; American Society of Anesthesiologist (ASA) Physical State Classification Score $\leq 3$; and age extremes. All these risk factors help in the identification of this diagnosis and in the evaluation of the patient's possibilities of presenting recovery delay. To avoid this delay in the patient's recovery, the nurse can identify the risk factors and thus prevent them ${ }^{(28)}$.

The ND risk for perioperative positioning injury presented the risk factor obesity most prevalent in adults, which requires attention in the prevention of damage and injuries in the postoperative period $^{(29)}$. The ND risk for infection, damages on skin and in dentition are expected in the surgical clinic patient ${ }^{(24-25)}$ corroborating the results shown in this study.

The ND impaired comfort is observed more frequently in the postoperative period ${ }^{(18)}$. However, the participants of the two groups of this research had the DC feeling of discomfort with a high rate, in addition to the RF symptoms related to the disease, referring to a reflection on the importance of care and assistance of nurses since the preoperative period.

Such evidence may be associated with the fact that the patient is in the process of preparation for a surgical procedure, which may generate changes in biopsychospiritual functions. It was also observed the presence of RF corresponding to the subjective questions of those who experience the surgical procedure, inherent to the perception of the individual and how he experiences them. Among them are losses, fear of death, anxiety about the procedure, how it will occur, dependence on other people and fear of the unknown ${ }^{(18,28)}$.

\section{Study limitation}

The limitations of the study occurred due to changes in the institutional setting, represented by the reduction in the number of beds, agglutination of some surgical wards and low numbers of hospitalized elderlies in the period of data collection. There was an increase in hospitalized patients with neoplasia, while they reduced or suppressed other surgeries scheduled for another time that did not included the period of data collection of this study.

\section{Contributions to the area of health}

Based on the diagnoses identified, it is expected to stimulate improvement in the quality of nursing care, especially during the preoperative period, providing a more accurate care. We suggest the development of complementary nursing care studies about the preoperative period, as well as the construction and validation of a specific nursing care instrument, in order to standardize professional communication using a standardized language, proposing early interventions to surgical patients. However, the development of the research allowed relevant data to infer that preoperative patients also have a high amount of ND and require differentiated nursing care.

\section{CONCLUSION}

The study reached the proposed objectives, identifying 80 ND, 15 main ND, which were repeated 164 times in the elderlies and 92 times in adults, with an average of 5 ND for each adult and 4.8 ND for each elderly. Of these diagnoses, 11 were focused on the problem and 4 on the risk, in addition to 63 identified defining characteristics.

This study made a comparison between the diagnoses of adults and elderlies. Thus, anxiety was observed as a common ND in both groups, while fear was, specifically, the most identified in adults and risk for infection in elderlies. With this study, it was possible to observe that the number of diagnoses found in the preoperative period exceeded the expectations found in the literature, sometimes being restricted to ED fear and anxiety. This finding brings the relevance of nursing care in the prevention of damage, reduction of time and cost of hospitalization, as well as postoperative complications.

\section{REFERENCES}

1. Kim H-J, Kim J-W, Jang S-N, Kim KD, Yoo J-I, Ha Y-C. Urinary incontinences are related with fall and fragility fractures in elderly population: nationwide cohort study. J Bone Metab. 2018;25(4):267-74. doi: 10.11005/jbm.2018.25.4.267

2. Ministério da Saúde (BR). Estatuto do Idoso [Internet]. 3a ed. Brasília: Ministério da Saúde; 2013 [cited 2016 Oct 15]. Available from: http:// bvsms.saude.gov.br/bvs/publicacoes/estatuto_idoso_3edicao.pdf.

3. Ministério da Saúde (BR). Ministério da Saúde destina R\$ 143,2 milhões para cirurgias eletivas [Internet]. Brasília; 2015 [cited 2016 Sep 28]. Available from: https://www.brasil.gov.br/noticias/saude/2015/07/governo-federal-destina-r-143-2-mi-para-realizacao-de-cirurgias-eletivas. 
4. Sánchez CA, Papapietro VK. Perioperative nutrition in ERAS Protocols. Rev Med Chil. 2017; 145(11):1447-53. doi: https://doi.org/10.4067/ s0034-98872017001101447

5. Dessotte CAM, Rodrigues HF, Furuya RK, Rossi LA, Dantas RAS. Stressors perceived by patients in the immediate postoperative of cardiac surgery. Rev Bras Enferm [Internet] 2016;69(4):694-703. doi: 10.1590/0034-7167.2016690418i

6. Novaes ES, Torres MM, Oliva APV. Nursing diagnoses in surgical clinic. Acta Paul Enferm. 2015;28(1):26-31. doi: 10.1590/1982-0194201500006

7. Lopes AER, Pompeo DA, Canini SRMS, Rossi LA. Nursing diagnoses of patients in the preoperative period of esophageal surgery. Rev LatinoAm Enfermagem. 2009;17(1):66-73. doi: 10.1590/S0104-11692009000100011

8. Sayin Y, Aksoy G. The nurse's role in providing information to surgical patients and family members in Turkey: a descriptive study. AORN J. 2012;95(6):772-87. doi: 10.1016/j.aorn.2011.06.012

9. Nilsson L, Lindberget O, Gupta A, Vegfors M. Implementing a pre-operative checklist to increase patient safety: a 1-year follow-up of personnel attitudes. Acta Anaesthesiol Scand. 2010;54(2):176-82. doi: 10.1111/j.1399-6576.2009.02109.x

10. Panunto MR, Guirardello EB. Nursing workload at a gastroenterology unit. Rev Latino-Am Enfermagem. 2009; 17(6):1009-14. doi: 10.1590/ S0104-11692009000600013

11. Conselho Federal de Enfermagem - COFEN. Resolução COFEN-358/2009. Dispõe sobre a Sistematização da Assistência de Enfermagem e a implementação do Processo de Enfermagem em ambientes públicos ou privados em que ocorre o cuidado profissional de Enfermagem, e dá outras providências [Internet]. Rio de Janeiro; 2009 [cited 2016 Aug 11]. Available from: http://www.cofen.gov.br/resoluocofen-3582009_4384.html

12. Herdman TH, Kamitsuru S. Diagnósticos de enfermagem da NANDA: definições e classificação, 2015-2017. 10ª ed. Porto Alegre: Artmed; 2015.

13. Ministério da Saúde (BR). Resolução n. 510, de 7 de abril de 2016 do Conselho Nacional de Saúde que define as diretrizes e normas regulamentadoras de pesquisas envolvendo seres humanos. Diário Oficial da União, Brasília, 24 de maio de 2016, Seção 1, p. 44-6.

14. Ministério da Saúde (BR). Resolução n. ${ }^{\circ} 466$ de 12 de dezembro de 2012 do Conselho Nacional de Saúde que define as diretrizes e normas regulamentadoras de pesquisas envolvendo seres humanos. Diário Oficial da União. Brasília, 13 de junho de 2013, Seção 1, p. 59-62.

15. Polit DF, Beck CT. Nursing Research. Generating and assessing evidence for nursing practice. 9th ed. Philadelphia (PA): Lippincott Williams \& Wilkins; 2012.

16. Vieira S. Introdução à bioestatística. 5a ed. Rio de Janeiro: Elsevier; 2015.

17. Sousa RM, Santana RF, Santo FHE, Almeida JG, Alves LAF. Nursing diagnoses identified in hospitalized elderly: association with geriatrics' syndromes. Esc Anna Nery. 2010;14(4):732-41. doi: 10.1590/S1414-81452010000400012

18. Bitencourt GR, Santana RF, Cavalcanti ACD, Cassiano KM. Comparação de diagnósticos de enfermagem em adultos e idosos hospitalizados no pós-operatório. Rev Eletr Enf. 2011;13(4):604-11. doi: 10.5216/ree.v13i4.15172

19. Pedroso LM, Melo RM, Silva Jr NJ. Comparative study of postoperative pain between the Lichtenstein and Laparoscopy surgical techniques for the treatment of unilateral primary inguinal hernia. Arq Bras Cir Dig. 2017;30(3):173-176. doi: 10.1590/0102-6720201700030003

20. Ministério da Saúde (BR). Morbidade hospitalar do SUS, por local de internação [Internet]. Rio de Janeiro; 2017 [cited 2017 Oct 15]. Available from: http://tabnet.datasus.gov.br/cgi/sih/midescr.htm

21. Tomasi AVR, Pires FRO, Durand MK, Danczuk RFT, Heidemann ITSB. Prevalence of surgery in elderly. Rev Enferm UFPE. 2017;11(9):3395-401. doi: 10.5205/reuol.11088-99027-5-ED.1109201710

22. Lins Neto MADF, Leão MJDR, Alves EC, Fontan AJ. Colon mechanical preparation is necessary as routine in medical care? Arq Bras Cir Dig. 2012;25(1):25-8. doi: 10.1590/S0102-67202012000100006

23. Ascari RA, Neiss M, Sartori AA, Silva OM, Ascari TM, Galli KSB. Perceptions of the surgical patient in the preoperative period concerning nursing care. Rev Enferm UFPE. 2013;7(4):1136-44. doi: 10.5205/1981-8963-v7i4a11590p1136-1144-2013

24. Perdue TO, Schreier A, Swanson M, Neil J, Carels R. Evolving self view and body image concerns in female postoperative bariatric surgery patients. J Clin Nurs. 2018;21(22):4018-4027. doi: 10.1111/jocn.14527

25. Baggio MA, Teixeira A, Portella MR. Pré-operatório do paciente cirúrgico cardíaco: a orientação de enfermagem fazendo a diferença. Rev Gaucha Enferm [Internet]. 2001 [cited 2017 Oct 16];22(1):122. Available from: http://www.seer.ufrgs.br/index.php/ RevistaGauchadeEnfermagem/article/view/4355/2303

26. Debone MC, Pedruncci ESN, Candido MCP, Marques S, Kusumota L. Nursing diagnosis in older adults with chronic kidney disease on hemodialysis. Rev Bras Enferm. 2017;70(4):800-5. doi: 10.1590/0034-7167-2017-0117.

27. Rezola-Pardo C, Arrieta H, Gil SM, Yanguas JJ, Iturburu M, Irazusta J, et al. A randomized controlled trial protocol to test the efficacy of a dualtask multicomponent exercise program in the attenuation of frailty in long-term nursing home residents: aging-ONDUAL-TASK study. BMC Geriatr. 2019;19(1):1-9. doi: 10.1186/s12877-018-1020-z

28. Rembold SM, Santana RF, Souza PA, Schwartz SMOX. Nursing diagnosis risk for delayed surgical recovery (00246): concept clarification and definition of empirical referents. Int J Nurs Knowl. 2017. doi: 10.1111/2047-3095.12176

29. Oliveira KF, Pires PS, De-Mattia AL, Barichello E, Galvão CM, Araújo CA, et al. Influence of support surfaces on the distribution of body interface pressure in surgical positioning. Rev Latino-Am Enfermagem. 2018;26:e3083. doi: 10.1590/1518-8345.2692.3083 